\title{
Opportunistic feeding on various organic food sources by the cold-water coral Lophelia pertusa
}

\author{
C. E. Mueller ${ }^{1}$, A. I. Larsson ${ }^{2}$, B. Veuger ${ }^{1}$, J. J. Middelburg ${ }^{3}$, and D. van Oevelen ${ }^{1}$ \\ ${ }^{1}$ Royal Netherlands Institute for Sea Research (NIOZ-Yerseke), P.O. Box 140, 4400 AC Yerseke, the Netherlands \\ ${ }^{2}$ Department of Marine Ecology, University of Gothenburg, Tjärnö, 45296 Strömstad, Sweden \\ ${ }^{3}$ Utrecht University, Department of Earth Sciences - Geochemistry, P.O. Box 80.021, 3508 TA Utrecht, the Netherlands
}

Correspondence to: C. E. Mueller (christina.mueller@nioz.nl)

Received: 18 June 2013 - Published in Biogeosciences Discuss.: 10 July 2013

Revised: 7 November 2013 - Accepted: 10 November 2013 - Published: 9 January 2014

\begin{abstract}
The ability of the cold-water coral Lophelia pertusa to exploit different food sources was investigated under standardized conditions in a flume. The tested food sources, dissolved organic matter (DOM, added as dissolved free amino acids), bacteria, algae, and zooplankton (Artemia) were deliberately enriched in ${ }^{13} \mathrm{C}$ and ${ }^{15} \mathrm{~N}$. The incorporation of ${ }^{13} \mathrm{C}$ and ${ }^{15} \mathrm{~N}$ was traced into bulk tissue, fatty acids, hydrolysable amino acids, and the skeleton $\left({ }^{13} \mathrm{C}\right.$ only $)$ of L. pertusa. Incorporation rates of carbon (ranging from 0.8 $\left.2.4 \mu \mathrm{g} \mathrm{g} \mathrm{g}^{-1} \mathrm{DW} \mathrm{d}^{-1}\right)$ and nitrogen $\left(0.2-0.8 \mu \mathrm{g} \mathrm{Ng}^{-1} \mathrm{DW}\right.$ $\mathrm{d}^{-1}$ ) into coral tissue did not differ significantly among food sources indicating an opportunistic feeding strategy. Although total food assimilation was comparable among sources, subsequent food processing was dependent on the type of food source ingested and recovery of assimilated $\mathrm{C}$ in tissue compounds ranged from $17 \%$ (algae) to $35 \%$ (Artemia). De novo synthesis of individual fatty acids by L. pertusa occurred in all treatments as indicated by the ${ }^{13} \mathrm{C}$ enrichment of individual phospholipid-derived fatty acids (PLFAs) in the coral that were absent in the added food sources. This indicates that the coral might be less dependent on its diet as a source of specific fatty acids than expected, with direct consequences for the interpretation of in situ observations on coral nutrition based on lipid profiles.
\end{abstract}

\section{Introduction}

Cold-water corals (CWCs) form reef structures in the cold and deep oceanic waters around the world (Roberts et al., 2009a; Davies and Guinotte, 2011). These reefs form hotspots of biodiversity (Roberts et al., 2006) and are important in carbon cycling along continental margins (van Oevelen et al., 2009). The high metabolic demand of CWC communities implies high food processing rates and indeed a close relationship between food availability and the occurrence of CWC reefs has been reported in many studies (Roberts et al., 2006; Thiem et al., 2006).

In the North Atlantic Ocean, CWC reef communities are primarily formed by the scleractinian coral Lophelia pertusa (Roberts et al., 2006). Recent in situ investigations using stable isotope and fatty acid analyses point to a close coupling of $L$. pertusa with pelagic resources such as zooplankton and phytodetritus (Spiro et al., 2000; Duineveld et al., 2004; Kiriakoulakis et al., 2005). While tidal pumping (Davies et al., 2009) and internal waves (Frederiksen et al., 1992; Duineveld et al., 2004) deliver a diverse range of particles to the coral, ranging from fresh to resuspended material, the vertical migration (daily or seasonal) of zooplankton can also contribute to the linkage between surface-water production and CWC nutrition (Hind et al., 2000; Valle-Levinson et al., 2004; Dodds et al., 2009).

Although organic food sources of various size, type and quality reach the CWC reefs, very little is currently known about their importance to the metabolism of CWCs or the biogeochemical processing that occurs following nutritional uptake. Analysis of natural stable isotope signatures in tissues allow insight into the coral nutrition as described above (Duineveld et al., 2004; Kiriakoulakis et al., 2005; Dodds et al., 2009; Roberts et al., 2009b; van Oevelen et al., 2009), but to enhance the resolution of bulk tissue isotope data, fatty acids are often used as a biomarkers in these studies 
(Kiriakoulakis et al., 2005; Dodds et al., 2009; Duineveld et al., 2012). However, the processing and production of fatty acids by CWCs has not yet been studied. This limits their interpretation since the use of fatty acids as biomarker for a specific food source critically depends on the assumption that these markers cannot be synthesized by the consumer itself (Kelly and Scheibling, 2012).

Feeding studies of $L$. pertusa so far have focused on uptake rates of Artemia salina (Purser et al., 2010; Tsounis et al., 2010) in the laboratory, but other food sources and particle sizes below $100 \mu \mathrm{m}$ have not been considered yet. The nutritional importance of a food source does not only depend on its availability, but also on uptake and physiological processing by $L$. pertusa. In addition to particulates, dissolved resources may also contribute to coral dietary requirements. For tropical corals, it is known that dissolved organic matter (DOM) can be an important food source even under low ambient DOM concentrations (Hoegh-Guldberg and Williamson, 1999; Grover et al., 2006, 2008). Recently, Naumann et al. (2011) reported DOM uptake by the CWC Desmophyllum dianthus; thus, DOM may be an additional resource for $L$. pertusa that has not yet been accounted for.

In addition to a demand of organic resources for energy and tissue growth, L. pertusa also needs an inorganic carbon source to sustain calcification. Two carbon sources are possibly involved in the calcification process in corals: dissolved inorganic carbon (DIC) from the surrounding seawater or metabolically generated $\mathrm{CO}_{2}$. While calcification in tropical zooxanthellate scleractinian corals is mainly $(70-75 \%)$ based on metabolic $\mathrm{CO}_{2}$ (Furla et al., 2000), the opposite seems to be true for the azooxanthellate octocoral Leptogorgia virgulata (Lucas and Knapp, 1997). Based on stable isotope data $\left(\delta^{18} \mathrm{O}, \delta^{13} \mathrm{C}\right)$, Adkins et al. (2003) suggested that $\mathrm{C}$ for calcification in azooxanthellate scleractinian CWCs is primarily derived externally rather than metabolically. Direct measurements distinguishing between the different calcification pathways in CWCs are however not available.

In this study we used standardized food quantities in a laboratory setting to trace the incorporation of stable isotope labelled food sources $\left({ }^{13} \mathrm{C}\right.$ and $\left.{ }^{15} \mathrm{~N}\right)$ to measure food uptake rates and potential preferences of the CWC L. pertusa. Different food sources were selected to cover different particle sizes and nutritional values $(\mathrm{C}: \mathrm{N}$ ratio), comprising dissolved organic matter, bacteria, algae and zooplankton (Artemia). Following food uptake we traced ${ }^{13} \mathrm{C}$ and ${ }^{15} \mathrm{~N}$ into two of the most important biochemical components, hydrolysable amino acids (HAAs) and lipids represented by the sum of total fatty acids (TFAs) to follow metabolic processing. Within the lipid pool we especially followed food-derived $\mathrm{C}$ further into phospholipid-derived fatty acids (PLFAs) to have a more detailed look into the synthesis of structural and therefore functional fatty acids. Additionally, we traced food-derived $\mathrm{C}$ into the coral skeleton to investigate the metabolic contribution to coral calcification.

\section{Methods}

\subsection{Sampling location and maintenance}

All corals used in the experiment were collected at the Tisler Reef, one of the largest and shallowest inshore reefs known so far. It is located at a depth of 70 to $155 \mathrm{~m}$ in the Skagerrak, on a sill forming the submarine border between Norway and Sweden. The current velocity over the reef varies from 0 to $50 \mathrm{~cm} \mathrm{~s}^{-1}$ throughout the year while the flow direction fluctuates irregularly between NW and SE (Lavaleye et al., 2009; Wagner et al., 2011). The amount and quality of particulate organic carbon (POC) entering the reef depend on the location within the reef, and concentrations vary between 43 to $106 \mu \mathrm{gOC} \mathrm{L}^{-1}$ (Wagner et al., 2011). Temperature at the reef site typically fluctuates between 6 and $9^{\circ} \mathrm{C}$ throughout the year (Lavaleye et al., 2009; Wagner et al., 2011).

Corals were collected from a depth of $117 \mathrm{~m}$ (N58 $59800^{\prime}$ E $10^{\circ} 58045^{\prime}$ ) using an ROV (Remotely Operated Vehicle, Sperre Subfighter 7500 DC). Within a few hours after sampling, corals were transported in cooling boxes filled with cold seawater $\left(7-8^{\circ} \mathrm{C}\right.$, salinity 31$)$ to the laboratory at the Sven Lovén Centre for Marine Sciences, Tjärnö, Sweden. Until the start of the experiment ( 3 months), corals were kept in a dark thermo-stated room at $7^{\circ} \mathrm{C}$ with a flow through of sand-filtered bottom water (particle size $1-2 \mathrm{~mm}$ ) from $45 \mathrm{~m}$ depth in the adjacent Koster fjord $\left(7-8^{\circ} \mathrm{C}\right.$, salinity 31$)$. During this time the corals were fed with larvae (nauplii) of the Brine Shrimp Artemia spp. every 3 to 4 days. The Sven Lovén Centre has kept $L$. pertusa alive and growing under these conditions for a number of years.

Coral samples used in this experiment were clipped to approximately the same size with $4.5 \pm 1.9 \mathrm{~g}$ dry weight (DW) and $8 \pm 4$ polyps per fragment (average \pm SD) about a week before the experiments started.

\subsection{Preparation of particulate labelled substrates}

CWCs are thought to thrive mainly on particulate organic matter (Duineveld et al., 2012). To test for assimilation of different food particle sizes, we chose bacteria to represent picoplankton and microalgae to represent nanoplankton. Artemia nauplii were chosen to represent mesozooplankton because they can be cultured in high densities, are the essential food source for successfully keeping $L$. pertusa in the laboratory and have been used in earlier CWC feeding studies (Purser et al., 2010; Tsounis et al., 2010; Naumann et al., 2011). While DOM was added in the form of a commercially available algal-derived mixture of dissolved free amino acids (Cambridge Isotopes, $\mathrm{U}^{13} \mathrm{C} 97-99 \%, \mathrm{U}{ }^{15} \mathrm{~N}$ 97-99\%, CNLM-452-0.5), the labelled POM food sources were prepared by culturing the respective organisms in the presence of ${ }^{13} \mathrm{C}$ and ${ }^{15} \mathrm{~N}$ labelled substrates. A natural community of bacteria was derived from a few $\mathrm{mL}$ of natural seawater, obtained from the Oosterschelde estuary (salinity 30) 
in the SW of the Netherlands. The water sample was added to $1 \mathrm{~L}$ culture medium (M63) containing $0.02 \mathrm{~mol} \mathrm{~L}^{-1}$ glucose (10 atom $\%{ }^{13} \mathrm{C}$, Cambridge Isotopes) and $0.01 \mathrm{~mol} \mathrm{~L}^{-1} \mathrm{am}-$ monium chloride (10 atom $\%{ }^{15} \mathrm{~N}$, Cambridge Isotopes). After 3 days of culturing in the dark, bacteria were concentrated by centrifugation $(14500 \mathrm{~g})$ and rinsed with $0.2 \mu \mathrm{m}$ filtered seawater to remove residual labelled substrates. Bacteria in the concentrate were kept frozen until use in the experiment.

The diatom Skeletonema costatum was cultured axenically in $4 \mathrm{~L} \quad \mathrm{~F} / 2$ culture medium containing $0.8 \mathrm{mmol} \mathrm{L}^{-1} \mathrm{NaNO}_{3} \quad\left(10\right.$ atom \% ${ }^{15} \mathrm{~N}$, Cambridge Isotopes) and $2 \mathrm{mmol} \mathrm{L}^{-1} \mathrm{NaHCO}_{3}\left(20\right.$ atom $\%{ }^{13} \mathrm{C}$, Cambridge Isotopes, $99 \%{ }^{13} \mathrm{C}$ ). After 3 weeks of culturing in $12 \mathrm{~h}$ light $12 \mathrm{~h}$ dark cycles (at a cell density of around $3-4 \times 10^{6}$ cells $\mathrm{mL}^{-1}$ ), algae were concentrated by centrifugation at $450 \mathrm{~g}$, rinsed three times with $0.2 \mu \mathrm{m}$ filtered seawater to remove residual labelled substrates and kept frozen until use in the experiment.

For culturing ${ }^{13} \mathrm{C}$ and ${ }^{15} \mathrm{~N}$ enriched Artemia nauplii, 6 times $0.1 \mathrm{~g}$ Artemia cysts (Sera) were incubated in $5 \mathrm{~L}$ incubation chambers filled with $0.2 \mu \mathrm{m}$ filtered seawater under natural light conditions and light aeration. After the larvae had developed to the state that they take up particulate food (1 to 2 days after eclosion of larvae), they were fed every second day with around 7 to $10 \mathrm{mgC}$ derived from ${ }^{13} \mathrm{C}$ and ${ }^{15} \mathrm{~N}$ enriched pre-cultured algae (cultured as described above, 4 atom $\%{ }^{13} \mathrm{C}, 10$ atom $\%{ }^{15} \mathrm{~N}$ ). The uptake of algae by Artemia was visually confirmed under the microscope. After seven days of feeding, the larvae were concentrated by filtration, rinsed with filtered seawater, counted under the binocular and stored frozen. Within the filtrate, different early larvae stages could be identified.

To standardize the amount of carbon added to the incubations, all substrates were measured for carbon and nitrogen content. ${ }^{13} \mathrm{C}$ and ${ }^{15} \mathrm{~N}$ enrichment and the fatty acid composition (PLFAs) of organic food sources were also measured to trace and calculate coral food uptake (see below for methodological description).

\subsection{Experimental setup and procedure}

During the incubations, corals were placed in recirculation flumes $(60 \mathrm{~L})$ in a thermo-stated room at $7{ }^{\circ} \mathrm{C}$ (Fig. 1). Water circulation was maintained by a motor-driven propeller situated in the returning pipe (for more details see Purser et al., 2010). Prior to the experiment, the flume was filled with $0.2 \mu \mathrm{m}$ filtered seawater from $45 \mathrm{~m}$ depth out of the Koster fjord (salinity $33.7^{\circ} \mathrm{C}, \mathrm{pH} 7.9$ on NBS scale) and the motor was set to ensure a flow speed of $7 \mathrm{~cm} \mathrm{~s}^{-1}$, which is within the natural range found at the Tisler Reef (Lavaleye et al., 2009; Wagner et al., 2011).

Three coral fragments were randomly selected and placed in the test section of each flume (Fig. 1). The three pieces were gently inserted into a $1 \mathrm{~cm}$ elastic silicone tube on an acrylic plate that could be attached to the flume base (Purser

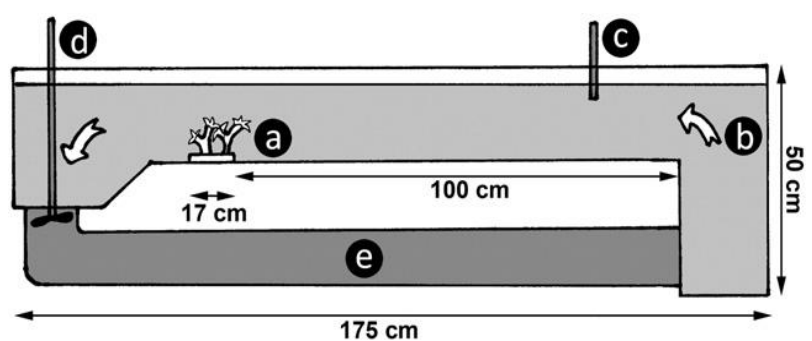

Fig. 1. Scale diagram of recirculation Plexiglas flume setup adopted from Purser et al. (2010). (a) test section with coral branches in plastic mount (depth $8 \mathrm{~cm}$ ), (b) direction of circulation, (c) food delivery point, (d) motor, (e) opaque plastic return pipe.

et al., 2010). Corals were left in the flume for $12 \mathrm{~h}$ to acclimatize to the conditions. After acclimation, $10 \mathrm{mg} \mathrm{C}$ of the respective food source per treatment was gently pipetted into the water column of each flume (final concentration $170 \mu \mathrm{g} \mathrm{C} \mathrm{L}^{-1}$ ). Visual observations confirmed that the circulating water kept the particulate food in suspension. Each flume contained three coral pieces and each food source was replicated twice. As a control treatment, corals were incubated for the same time without any food addition. After an incubation time of 4 days in darkness, coral samples were frozen at $-20^{\circ} \mathrm{C}$, freeze-dried and stored frozen for further analysis.

\subsection{Sample treatment and analyses}

After freeze-drying, coral samples were weighed and homogenized by grinding with a ball mill for $20 \mathrm{~s}$ (MM 2000, Retsch, Haan, Germany). A subsample of around $30 \mathrm{mg}$ of ground material (organic and inorganic fraction) was transferred to pre-combusted silver boats and analyzed for isotopic ratio and $\mathrm{C} / \mathrm{N}$ content using a Thermo Electron FlashEA 1112 analyzer (EA) coupled to a Delta V isotope ratio mass spectrometer (IRMS). Another subsample was transferred to a silver boat, acidified stepwise with drops of increasing concentrated $\mathrm{HCl}$ until the inorganic $\mathrm{C}$ fraction was removed (no bubbling after acid addition). The remaining material was analyzed on the EA-IRMS for isotopic ratio and organic $\mathrm{C}$ content. Incorporation of $\mathrm{C}$ in the inorganic skeleton was determined by subtraction of the organic carbon fraction (tissue + organic matrix) from the total carbon pool.

Total fatty acids (TFAs) were extracted with an adjusted Blight Dyer method. A part of the total fatty acid extract was further eluted over a silica column (Merck Kieselgel $60)$ to isolate the phospholipid-derived fatty acids (PLFAs) (Boschker et al., 1999). The TFA and PLFA extracts were then further derivatized by mild alkaline transmethylation to obtain fatty acid methyl esters (FAME). Preparation of methyl esters was carried out following the method of Boschker et al. (1999). For extraction, 0.7 g DW of coral 
samples, $\sim 100 \mu \mathrm{L}$ of DOM and smaller particulate food sources, and 100 Artemia (equivalent to $500 \mu \mathrm{g} \mathrm{C}$ and $50 \mu \mathrm{g} \mathrm{C}$ respectively) were used. Concentration and carbon isotopic composition of individual TFAs and PLFAs were measured on a gas-chromatograph combustion-interface isotope-ratio mass spectrometer (GC-c- IRMS) according to Boschker et al. (1999).

Hydrolysable amino acids (HAAs) were extracted and analyzed following Veuger et al. (2005). Ground coral samples were first treated with $12 \mathrm{~mol} \mathrm{~L}^{-1} \mathrm{HCl}$ to dissolve the skeleton by repeated addition of $\mathrm{HCl}$ drops to avoid loss of sample through bubbling. The remaining material was then hydrolyzed in $6 \mathrm{~mol} \mathrm{~L}^{-1} \mathrm{HCl}$ at $110^{\circ} \mathrm{C}$ for $20 \mathrm{~h}$ and purified by cation-exchange chromatography (Dowex 50WX8 resin). The hydrolysable amino acids were derivatized with isopropanol and pentafluoropropionic anhydride and analyzed by GC-c-IRMS for concentrations and ${ }^{13} \mathrm{C}$ and ${ }^{15} \mathrm{~N}$ content.

Stable isotope data are expressed in delta notation as $\delta X \% o=\left(R_{\text {sample }} / R_{\text {ref }-1}\right) \cdot 1000$, in which $X$ represents $\mathrm{C}$ or N, $R_{\text {sample }}$ is the heavy/light isotope ratio in the sample (e.g., ${ }^{13} \mathrm{C} /{ }^{12} \mathrm{C}$ ) and $R_{\text {ref }}$ is the heavy/light isotope ratio of the reference material $\left(R_{\text {ref }}=0.01118\right.$ for $\mathrm{C}$ and $R_{\text {ref }}=0.00368$ for $\left.\mathrm{N}\right)$. The atomic $\%$ of the heavy isotope in a sample (e.g., $\left.{ }^{13} \mathrm{C} /\left({ }^{13} \mathrm{C}+{ }^{12} \mathrm{C}\right)\right)$ was calculated as $F=$ $R_{\text {sample }} /\left(R_{\text {sample }+1}\right.$. The excess (above background) atom $\%$ is the difference between the $F$ in an experimental sample and the atom $\%$ in a background (untreated) coral sample: $E=F_{\text {sample }}-F_{\text {background }}$, so that zero values of $E$ imply no uptake of the isotopically labelled food source and positive values indicates food uptake. To correct for differences in isotope enrichment among the food sources, the excess incorporation was divided by the atom\% of each specific food source, e.g., 0.09 for bacteria $\mathrm{C}$ and 0.1 for bacteria N. To arrive at total elemental uptake, $E$ was multiplied with $\mathrm{C}$ or $\mathrm{N}$ content of $1 \mathrm{~g}$ DW sample ( $\mu \mathrm{g} \mathrm{C} \mathrm{g}^{-1}$ DW sample, $\mu \mathrm{g} \mathrm{N} \mathrm{g}^{-1}$ DW sample). All results are reported as average $\pm \mathrm{SD}$ derived from all coral pieces per treatment $(n=6)$.

\subsection{Statistical analyses}

To be able to perform statistical analyses of the obtained data, we treated pseudo-replicates as true replicates if no significant different between flumes were found by using KruskalWallis Test ( $p \geq 0.05)$. However, all statistical values still to be considered with care because of limited replication. The potential influence of food sources on $\mathrm{C}$ and $\mathrm{N}$ uptake in bulk tissue and specific components was investigated using Kruskal-Wallis Test since a normal distribution for some data could not be achieved by data transformation. However, in cases where all requirements for an ANOVA were met, the results did not differ from the ones obtained by KruskalWallis Tests. Therefore we decided to use Kruskal-Wallis Tests for all factors. Differences among treatments were then further investigated using a Wilcoxon rank-sum test for pair-
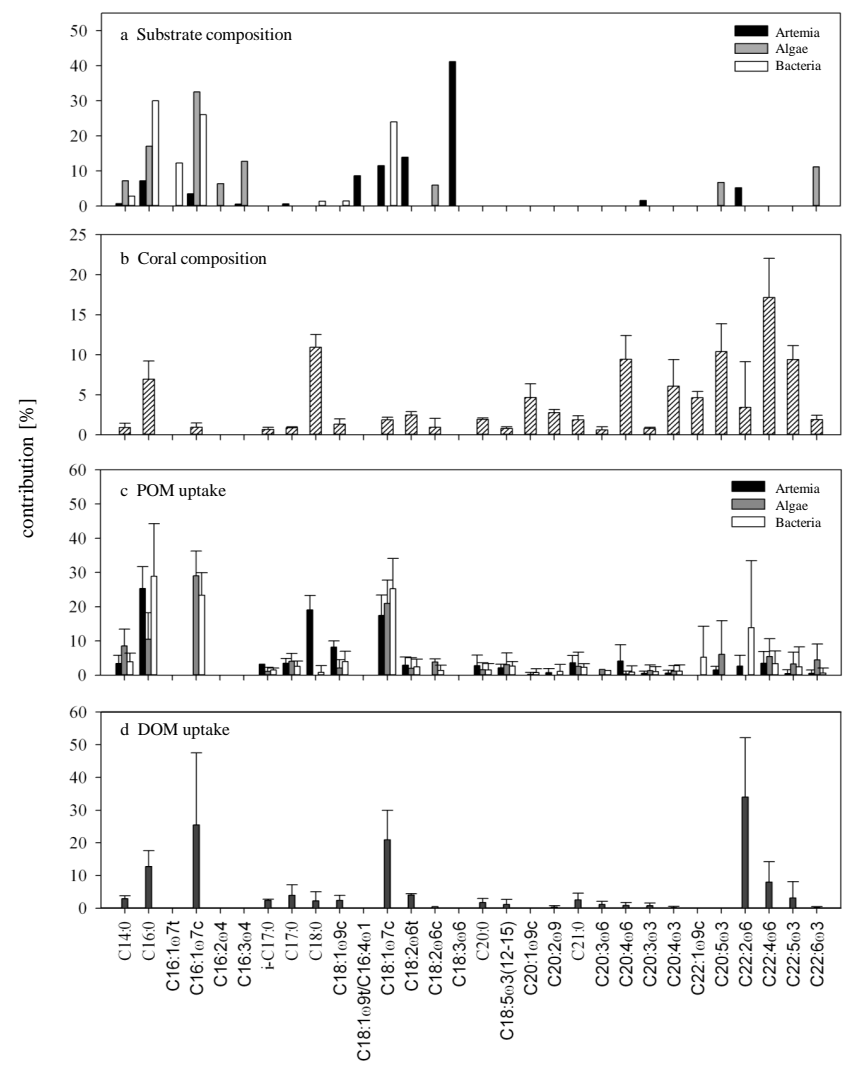

Fig. 2. PLFA profiles of (a) the particulate organic food sources Artemia, algae and bacteria (\% contribution to total concentration), (b) L. pertusa, (c) POM-derived C incorporation into coral PLFAs by L. pertusa and (d) DOM transformation into coral PLFAs by L. pertusa (\% contribution to total uptake). The bars in each figure represent average \pm SD.

wise comparison with an adjustment of $p$ values by the Bonferroni method.

\section{Results}

\subsection{Biogeochemical characteristics of particulate food sources}

All food sources were significantly isotopically enriched above background and differed considerably in food quality represented by $\mathrm{C} / \mathrm{N}$ ratios and PLFA contents as well as compositions in case of particulate organic food sources (Table 1, Fig. 2a). Accordingly, the bacteria-derived PLFA pool was dominated by $\mathrm{C} 16: 1 \omega 7 \mathrm{c} / \mathrm{t}, \mathrm{C} 16: 0$ and $\mathrm{C} 18: 1 \omega 7 \mathrm{c}$ and the algal-derived PLFA pool by $\mathrm{C} 16: 0, \mathrm{C} 16: 1 \omega 7 \mathrm{c}$, followed by $\mathrm{C} 16: 3 \omega 4, \mathrm{C} 20: 5 \omega 3$ and $\mathrm{C} 22: 6 \omega 3$ (Fig. 2a). Artemiaderived PLFAs mainly comprised $\mathrm{C} 18: 3 \omega 6$, followed by

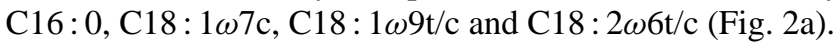


Table 1. Characteristics of food sources used during the experiment.

\begin{tabular}{lcccc}
\hline Food source & ${ }^{13} \mathrm{C}(\mathrm{at} \%)$ & ${ }^{15} \mathrm{~N}($ at $\%)$ & Molar C/N ratio & $\begin{array}{c}\text { PLFA } \\
\text { content }(\% \mathrm{C})\end{array}$ \\
\hline Amino acids (DOM) & 99 & 99 & 5.0 & 0.00 \\
Bacteria (BAC) & 9 & 10 & 3.6 & 0.31 \\
Algae (ALG) & 3 & 10 & 9.8 & 0.03 \\
Zooplankton (ART) & 3 & 2 & 4.2 & 0.32 \\
\hline
\end{tabular}

\subsection{Biogeochemical characteristics of $L$. pertusa}

Corals used in this experiment had a total $\mathrm{C}$ content of $128 \pm 5 \mathrm{mg} \mathrm{C} \mathrm{g}^{-1}$ DW coral. This total $\mathrm{C}$ was partitioned into an organic tissue fraction of $13 \%$ and inorganic skeleton fraction of $87 \%$. The organic $\mathrm{C}$ in the tissue fraction could be further partitioned into $24 \%$ of THAAs, $7 \%$ TFAs and $0.04 \%$ PLFAs (Table 2). Dominant PLFAs in the coral tissue were $\mathrm{C} 16: 0, \mathrm{C} 18: 0, \mathrm{C} 20: 4 \omega 3, \mathrm{C} 20: 4 \omega 6, \mathrm{C} 20: 5 \omega 3$, $\mathrm{C} 22: 4 \omega 6$ and $\mathrm{C} 22: 5 \omega 3$ (all $>5 \%$ ), followed by $\mathrm{C} 20: 1 \omega 9 \mathrm{c}$ and $\mathrm{C} 22: 1 \omega 9 \mathrm{c}(\sim 5 \%$, Fig. 2b). No significant difference in coral $\mathrm{C}$ content in tissue, TFAs or PLFAs was detected between the coral pieces in the different food treatments (Kruskal-Wallis $p>0.05$ for all comparisons). Organic N content of corals used in this experiment was $3 \pm 1 \mathrm{mg} \mathrm{N} \mathrm{g}^{-1}$ DW coral, with $12 \%$ of the $\mathrm{N}$ present in the THAA fraction (Table 2). No significant difference in coral $\mathrm{N}$ content in tissue and THAAs was detected between the coral pieces in the different food treatments (Kruskal-Wallis $p>0.05$ ).

\subsection{Total $\mathrm{C}$ and $\mathrm{N}$ assimilation}

The assimilation of $\mathrm{C}$ from the food sources into coral tissue was not significantly different among treatments (Wilcoxon $p>0.05$ for all comparisons, Fig. 3a). Artemia-derived C was assimilated at a rate of $1884 \pm 1067 \mathrm{ng} \mathrm{Cg}^{-1} \mathrm{DW}$ coral d $\mathrm{d}^{-1}$, algal-derived $\mathrm{C}$ with $1520 \pm 498 \mathrm{ng} \mathrm{Cg}^{-1} \mathrm{DW}_{\text {coral d }}{ }^{-1}$, bacterial-derived $\mathrm{C}$ with $750 \pm 458 \mathrm{ng} \mathrm{C} \mathrm{g}^{-1} \mathrm{DW}$ coral d $\mathrm{d}^{-1}$ and DOM with $2393 \pm 1221 \mathrm{ng} \mathrm{C} \mathrm{g}^{-1}$ DW coral d ${ }^{-1}$. Also $\mathrm{N}$ was assimilated comparably among different food sources by $L$. pertusa (Wilcoxon $p>0.05$ for all comparisons) with Artemia-derived N assimilated with $797 \pm 399 \mathrm{ng} \mathrm{N} \mathrm{g}^{-1}$ DW coral $\mathrm{d}^{-1}$, algal-derived $\mathrm{N}$ with $247 \pm 174 \mathrm{ng} \mathrm{N} \mathrm{g}^{-1}$ DW coral d ${ }^{-1}$ ) bacterial-derived $\mathrm{N}$ with $399 \pm 200 \mathrm{ng} \mathrm{N} \mathrm{g}^{-1}$ DW d ${ }^{-1}$ and DOM with $797 \pm 258 \mathrm{ng} \mathrm{N} \mathrm{g}^{-1}$ DW coral d ${ }^{-1}$ (Fig. 3a).

With the exception of corals fed with DOM (KruskalWallis $p=0.006$, Fig. 3a), C assimilation did not differ significantly from $\mathrm{N}$ assimilation among corals fed with particulate sources (Kruskal-Wallis $p>0.05$ ), regardless of different $\mathrm{N}$ additions per treatment due to fixed $\mathrm{C}$ additions and variable $\mathrm{C} / \mathrm{N}$ ratios of food sources. This points to a higher retention of nitrogen during assimilation and metabolic processing (Fig. 3e).
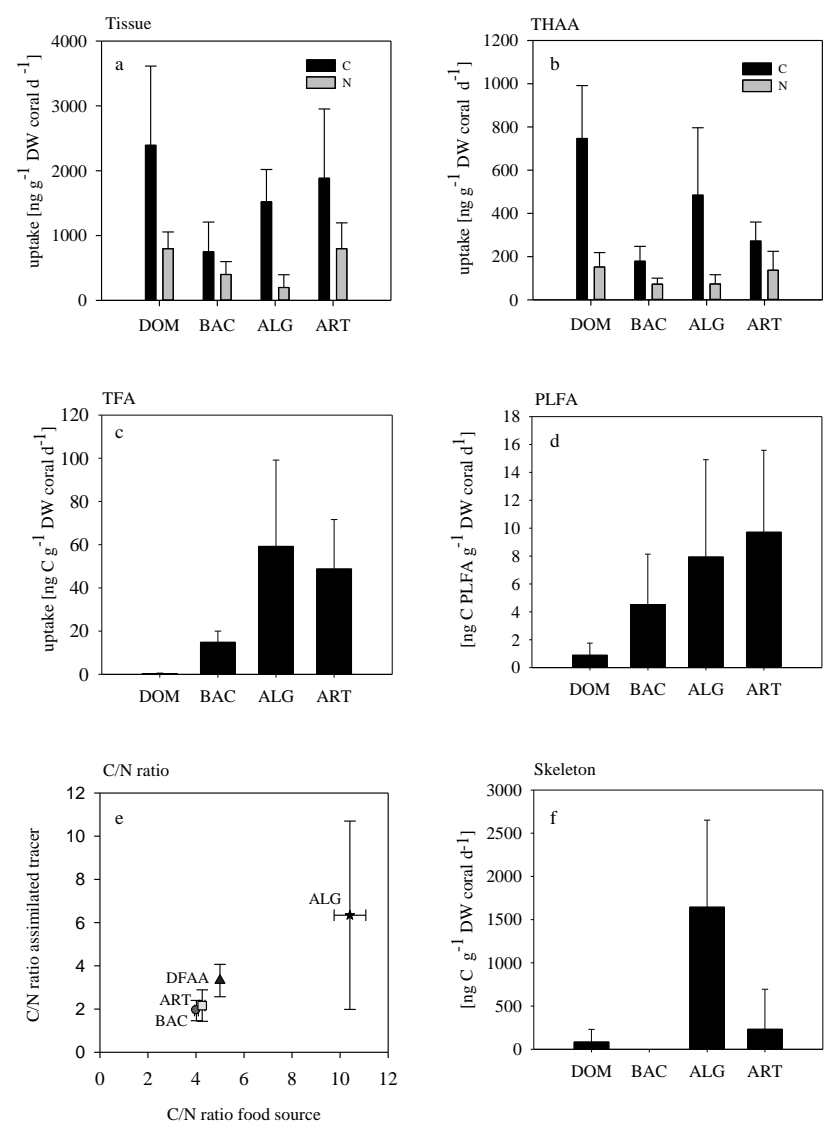

Fig. 3. (a) $\mathrm{C}$ and $\mathrm{N}$ uptake in coral tissue (note: different $\mathrm{C} / \mathrm{N}$ ratios of sources), (b) $\mathrm{C}$ and $\mathrm{N}$ uptake in THAAs of coral samples (note: different $\mathrm{C} / \mathrm{N}$ ratios of sources), (c) $\mathrm{C}$ uptake in TFAs of coral samples, (d) $\mathrm{C}$ uptake in PLFAs of coral samples, (e) $\mathrm{C} / \mathrm{N}$ ratio of food provided and of assimilation, (f) $\mathrm{C}$ uptake in coral skeleton. The bars in each figure represent average \pm SD.

\subsection{Food processing tracer incorporation in amino acids}

Between 14 to $32 \%$ of the total assimilated carbon was incorporated into the total hydrolysable amino acid pool (THAA) of $L$. pertusa. DOM-derived $\mathrm{C}$ was assimilated into THAAs at a significantly higher rate $\left(746 \pm 244 \mathrm{ng} \mathrm{Cg}^{-1}\right.$ DW coral $\left.\mathrm{d}^{-1}\right)$ than bacteria and Artemia-derived C $\quad\left(178 \pm 69 \mathrm{ng} \mathrm{C} \mathrm{g}^{-1}\right.$ DW coral $\mathrm{d}^{-1}$ 
Table 2. Biogeochemical composition of L. pertusa: Concentration of total carbon (Total C), organic carbon (Org C), total nitrogen (Total $\mathrm{N}$ ), total hydrolysable amino acids (THAAs), total fatty acids (TFAs) and phospholipid-derived fatty acids (PLFAs) in coral samples. Values are presented in $\left(\mathrm{mg} \mathrm{Cg}^{-1} \mathrm{DW}\right.$ coral $\left.\pm \mathrm{SD}\right)$ and $\left(\mathrm{mg} \mathrm{N} \mathrm{g}^{-1} \mathrm{DW}\right.$ coral $\left.\pm \mathrm{SD}\right)$, respectively.

\begin{tabular}{cccccc}
\hline Total C & Org C & Total N & THAAs & TFAs & PLFAs \\
\hline $128.05 \pm 4.95$ & $1.60 \pm 4.81$ & & $3.61 \pm 0.55(\mathrm{C})$ & $1.02 \pm 0.03$ & $0.06 \pm 0.02$ \\
& & $2.79 \pm 0.95(\mathrm{~N})$ & $0.34 \pm 0.05(\mathrm{~N})$ & & \\
\hline
\end{tabular}

and $272 \pm 88 \mathrm{ng} \mathrm{C} \mathrm{g}^{-1} \mathrm{DW}$ coral $\mathrm{d}^{-1}$, respectively, Wilcoxon $\left.p_{\text {DOM-BAC } / \mathrm{ART}}=0.03\right)$. The incorporation of algal-derived $\mathrm{C}\left(484 \pm 311 \mathrm{ng} \mathrm{C} \mathrm{g}^{-1}\right.$ DW coral d $\left.\mathrm{d}^{-1}\right)$ did not differ significantly from that of the other food sources (Wilcoxon $p>0.05$ for all comparisons).

The incorporation of $\mathrm{N}$ into THAAs represented up to $30 \%$ of the total $\mathrm{N}$ assimilated by the coral and did not differ significantly between food treatments (Kruskal-Wallis $p=0.2$ ) with $152 \pm 67 \mathrm{ng} \mathrm{N} \mathrm{g}^{-1} \mathrm{DW}$ coral $\mathrm{d}^{-1}$ for DOM, $137 \pm 87 \mathrm{ng} \mathrm{Ng}^{-1}$ DW coral $\mathrm{d}^{-1}$ for Artemia, $73 \pm 43 \mathrm{ng} \mathrm{Ng}^{-1} \mathrm{DW}$ coral $\mathrm{d}^{-1}$ for algae and $72 \pm 27 \mathrm{ng} \mathrm{N} \mathrm{g}^{-1}$ DW coral d ${ }^{-1}$ for bacteria (Fig. 3b).

\subsection{C incorporation into fatty acids}

Of the total $\mathrm{C}$ assimilated up to $4 \%$ was traced in the total fatty acid pool (TFA) of L. pertusa. The ingested food source hereby significantly influenced the amount of $\mathrm{C}$ incorporated into TFAs (Kruskal-Wallis $p=0.0003$, Fig. 3c). DOMderived $\mathrm{C}$ incorporation was significantly lower than that of the particulate sources $\left(0.3 \pm 0.2 \mathrm{ng} \mathrm{Cg}^{-1} \mathrm{DW}_{\text {coral d }}{ }^{-1}\right.$,

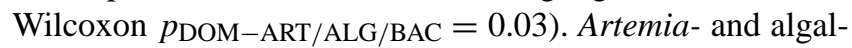
derived $\mathrm{C}$ (Wilcoxon $p>0.05$ ) were incorporated in TFAs at comparable rates, $49 \pm 23$ and $59 \pm 40 \mathrm{ng} \mathrm{C} \mathrm{g}^{-1} \mathrm{DW}$ coral $\mathrm{d}^{-1}$, respectively, but bacteria-derived $\mathrm{C}$ was incorporated at a significantly lower rate of $15 \pm 5 \mathrm{ng} \mathrm{C} \mathrm{g}^{-1} \mathrm{DW}$ coral d $\mathrm{d}^{-1}$ (Wilcoxon $p_{\mathrm{BAC}-\mathrm{ART}}=0.03$, Wilcoxon $p_{\mathrm{BAC}-\mathrm{ALG}}=0.05$, Fig. 3c).

The incorporation into the phospholipid-derived fatty acid (PLFA) C-pool accounted for $0.6 \%$ of total assimilated C. Like for TFAs, C incorporated into PLFAs was also significantly different between different food sources (Kruskal-Wallis $p=0.002$ ). Again, DOM-derived $\mathrm{C}$ was incorporated at a significant lower rate (1 $\pm 1 \mathrm{ng} \mathrm{Cg}^{-1}$ DW coral $\mathrm{d}^{-1}$ ) than any of the particulate sources (Wilcoxon $p_{\mathrm{DOM}-\mathrm{ART} / \mathrm{ALG}}=0.03$, Wilcoxon $p_{\text {DOM }-\mathrm{BAC}}=0.05$, Fig. $\left.3 \mathrm{~d}\right)$. The particulate sources however did not differ significantly in their incorporation (Wilcoxon $p>0.05$ for all comparisons). On average Artemia-derived $\mathrm{C}$ was incorporated with $10 \pm 6 \mathrm{ng} \mathrm{Cg}^{-1} \mathrm{DW} \mathrm{d}^{-1}$, algalderived $\mathrm{C}$ with $8 \pm 7 \mathrm{ng} \mathrm{Cg}^{-1} \mathrm{DW}$ coral d ${ }^{-1}$ and bacteriaderived $\mathrm{C}$ with $5 \pm 4 \mathrm{ng} \mathrm{Cg}^{-1} \mathrm{DW}$ coral d ${ }^{-1}$.

The incorporation of $\mathrm{C}$ into PLFAs in corals fed with DOM was solely caused by de novo synthesis, since the DOM source did not contain any PLFAs. The PLFAs C16 : 0, $\mathrm{C} 16: 1 \omega 7$ and $\mathrm{C} 18: 1 \omega 7 \mathrm{c}$ showed highest $\mathrm{C}$ incorporation

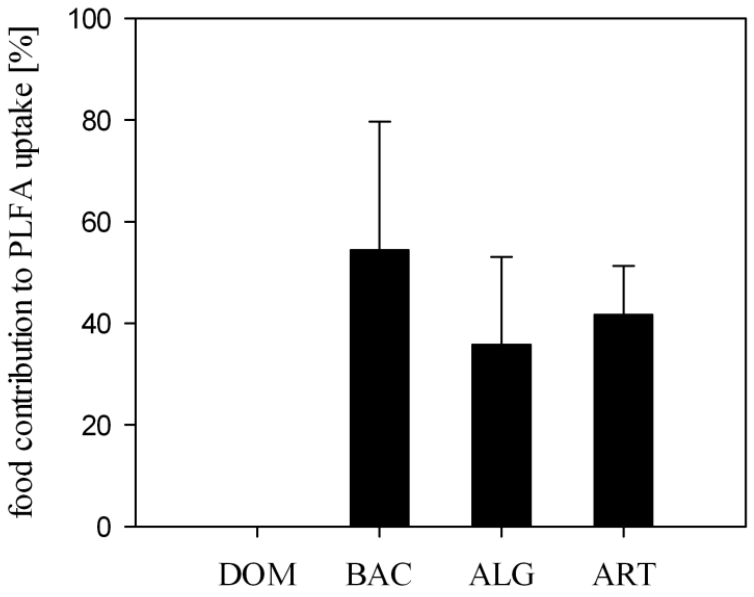

Fig. 4. Contribution of food-derived PLFAs to total PLFA synthesis in corals during the experiment. Based on the assumption that food-derived PLFAs are directly incorporated into animal PLFAs, the food contribution was calculated by summing the uptake in food characteristic PLFAs by $L$. pertusa and dividing it by its the total PLFA uptake. The bars in the figure represent average \pm SD.

but also long chain PLFAs like C22 : $2 \omega 6$ and C22 : $4 \omega 6$ incorporated tracer $\mathrm{C}$ in DOM fed corals (Fig. 2d). For particulate sources over 40-60\% of the assimilated PLFA-C by the corals was incorporated in PLFAs characterizing the respective food source (Fig. 4). PLFAs not present in the diet but with substantial tracer incorporation ( $>4 \%$ contribution to tracer uptake) were $\mathrm{C} 18: 0, \mathrm{C} 18: 1 \omega 9 \mathrm{c}$ and $\mathrm{C} 20: 4 \omega 6$ in

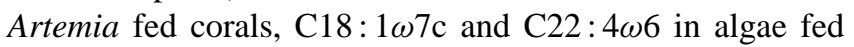
corals and $\mathrm{C} 22: 2 \omega 6$ and $\mathrm{C} 22: 1 \omega 9 \mathrm{c}$ in bacteria fed corals (Fig. 2c).

\subsection{Carbon incorporation into coral skeleton}

Incorporation of metabolic $\mathrm{C}$ derived from the processing of organic food sources into the inorganic carbonate skeleton was highly variable among coral samples (Fig. 3f), partly because only 1-2 coral pieces out of 6 showed measurable incorporation. Incorporation into the coral skeleton was highest in the algal treatment $\left(1.6 \pm 1.0 \mathrm{ug} \mathrm{C} \mathrm{g}^{-1} \mathrm{DW}\right.$ coral d $\left.{ }^{-1}\right)$, followed by the Artemia $\left(0.2 \pm 0.5 \mathrm{ug} \mathrm{C} \mathrm{g}^{-1} \mathrm{DW}\right.$ coral d $\left.\mathrm{d}^{-1}\right)$ and DOM $\left(0.08 \pm 0.15 \mathrm{ug} \mathrm{Cg}^{-1} \mathrm{DW}\right.$ coral $\left.\mathrm{d}^{-1}\right)$ treatment. Coral pieces fed with bacteria did not incorporate tracer $\mathrm{C}$ in their skeleton. 


\section{Discussion}

\subsection{Biochemical characteristics of $L$. pertusa}

The overall contribution of amino acids and fatty acids to C tissue is in agreement with observations on other organisms, including tropical corals, in which proteins form the largest fraction before sugars and lipids (Szmant-Froelich and Pilson, 1980; Achituv et al., 1994).

The concentration of total fatty acids $\left(20 \mathrm{mg} \mathrm{g}^{-1}\right.$ DW tissue with tissue DW contributing $5 \%$ to total DW, as observed in this study), however, was below the range of 55$124 \mathrm{mg} \mathrm{g}^{-1}$ DW tissue reported by Dodds et al. (2009) for $L$. pertusa from Rockall Bank, Mingulay Reef and New England Seamounts. Local differences can be responsible for this discrepancy as Larsson et al. (2013a) reported storage fatty acids concentrations of 15 to $19 \mathrm{mg} \mathrm{g}^{-1}$ DW tissue from $L$. pertusa collected at the Tisler Reef but also the maintenance in aquaria (3 month in this study) might have altered the lipid content (Larsson et al., 2013b).

\subsection{Food assimilation and source preferences}

In line with aquaria studies and in situ observations (BuhlMortensen, 2001; Freiwald et al., 2002; Tsounis et al., 2010) our study confirms that $L$. pertusa can utilize various particulate resources from a broad range of sizes including bacteria, algae and zooplankton. The assimilation of DOM by $L$. pertusa is in accordance with the observation that Desmophyllum dianthus took up DOM $\left(\sim 6 \mu \mathrm{g} \mathrm{C} \mathrm{g}-1 \mathrm{DW} \mathrm{d}^{-1}\right)$ during core incubations at a 10-100x lower DOC concentration (Naumann et al., 2011). The comparable assimilation rates among resources hereby suggest that $L$. pertusa feeds rather unselectively at equivalent concentrations. This, together with the indication that coral food uptake is primarily driven by external factors such as food availability and current velocity (Purser et al., 2010), suggests that $L$. pertusa is an opportunistic feeder that utilizes resources depending on availability.

Rates of $\mathrm{C}$ assimilation into the tissue/biomass of $L$. pertusa in this study $\left(\sim 2 \mu \mathrm{gOC}^{-1} \mathrm{DW}\right.$ coral $\left.\mathrm{d}^{-1}\right)$ are lower than the Artemia capture rates measured by Purser et al. (2010) under comparable flow and food conditions $\left(324 \mu \mathrm{g} \mathrm{POC} \mathrm{g}^{-1} \mathrm{DW}\right.$ coral d ${ }^{-1}$ ). These measurements however are difficult to compare, because capture rates may overestimate actual ingestion if not every prey item is successfully transferred to the gut (Purser et al., 2010) and tissue assimilation only represents a fraction of the total uptake as respiration and mucus excretion are ignored. Especially the latter can be a significant component of the energy budget of L. pertusa (Wild et al., 2008; Maier et al., 2011).
4.3 Food composition governs transfer into amino acids and lipids

Although the food sources were unselectively assimilated, there were clear differences in the metabolic processing. The most pronounced difference was observed between DOMand POM-derived C incorporation. While POM-derived C was incorporated at a higher rate than DOM-derived $\mathrm{C}$ in fatty acids, DOM-derived $\mathrm{C}$ was incorporated at higher rates in amino acids than POM-derived $\mathrm{C}$, excluding algal-derived C. This difference was most likely caused by the differences in composition between the sources. The DOM consisted solely of dissolved free amino acids, which can be directly incorporated into coral tissue amino acids, whereas fatty acids had to be produced de novo using amino acids as C-substrate. The POM sources contained among others amino acids and fatty acids. The comparatively high POM incorporation into coral fatty acids most likely results from their availability in the source and their (direct) assimilation by the coral as illustrated by the effective incorporation of dietary PLFAs into coral PLFAs (Fig. 4).

Our results further indicate that not only the quantity (concentration) of amino acids/fatty acids, present in a food sources, but also their quality (composition) might affect food source processing. This is especially illustrated by the assimilation of algae in comparison to other POM sources. Algal-derived $\mathrm{C}$ was incorporated into coral PLFAs at a comparable rate to other POM sources, despite containing 10 times less PLFA-derived C (Table 1). Additionally, algalderived $\mathrm{N}$ incorporation into coral tissue and amino acids did not significantly differ from the incorporation of other POM sources despite a higher $\mathrm{C} / \mathrm{N}$ ratio (i.e., a lower $\mathrm{N}$ concentration in the algal source). This suggests that while total assimilation can be comparable among sources, their nutritional importance in sustaining tissue components can still differ.

\subsection{Assimilation and synthesis of PLFAs}

Fatty acids are often used as biomarkers to infer the diet of animals (Braeckman et al., 2012; Kelly and Scheibling, 2012). This approach relies on the assumption that the relative composition of the PLFA pool in the animal reflects that of its food source(s) and hence that there is no alteration/modification or production of PLFAs occurring during the transfer from food source to animal. However this approach is only valid if the respective animal cannot synthesize the biomarker.

Overall, PLFA assimilation profiles (Fig. 2c, d) followed the biomarker concept and more closely reflected the dietary PLFA profiles (Fig. 2a) than that of the coral (Fig. 2a) with highest tracer recovery in PLFAs $<\mathrm{C} 20: 0$ chain length. However, a detailed profile comparison revealed that direct assimilation of dietary PLFAs from particulate sources could only explain 40 to $60 \%$ of the total C incorporation into the coral PLFAs. The remainder of the incorporation was due to 
de novo synthesis or alteration of dietary PLFAs. This capability of $L$. pertusa of de novo synthesis was also evident from the assimilation of DOM into coral PLFAs because this resource solely contained amino acids and no PLFAs. The assumption of the biomarker concept "you are what you eat" therefore might not be completely true for $L$. pertusa.

Additionally, the de novo synthesis of FAs by $L$. pertusa includes also FAs which have previously been used as biomarkers. For example, $\mathrm{C} 20: 5 \omega 3$ and $\mathrm{C} 22: 6 \omega 3$ (biomarkers for diatoms and dinoflagellates, respectively, Harwood and Russell, 1984) were synthesized by $L$. pertusa from Artemia. Furthermore C22:1 $\omega 9 \mathrm{c}$, a zooplankton biomarker (Sargent and Falkpetersen, 1988), was synthesized by L. pertusa when fed bacteria (detected in one of the three samples). Although the variation in de novo synthesis is high, it may complicate the interpretation of fatty acid profiles from field collected specimens, because presumed "unique" fatty acids may have been (partly) synthesized by L. pertusa. Our study thus adds to the growing evidence that care should be taken using fatty acids as dietary tracers in benthic food webs (Kelly and Scheibling, 2012; McLeod et al., 2013).

\subsection{Metabolic versus external $\mathrm{C}$ incorporation into coral skeleton}

Inorganic carbon to sustain calcification can either originate from an external (dissolved inorganic C) or from an internal pool (metabolic-derived C). In this study we directly measured the transfer of metabolic-derived $\mathrm{C}$ transfer into the coral skeleton, which ranged from $0.1-1.6 \mu \mathrm{g} \mathrm{C}_{\text {day }}{ }^{-1} \mathrm{~g}^{-1}$ DW coral depending on the food source. This rate is considerably lower than separate, but comparable, incubations with ${ }^{13} \mathrm{C}$-bicarbonate that showed a direct external inorganic C uptake of $46 \pm 25 \mu \mathrm{g} \mathrm{Cg}^{-1}$ DW coral d $\mathrm{d}^{-1}$ (Mueller et al. unpubl. data). Maier et al. (2009) measured a total calcification rate, i.e., sum of internal and external usage, of 23$78 \mu \mathrm{g} \mathrm{C}$ day ${ }^{-1} \mathrm{~g}^{-1}$ DW coral with ${ }^{45} \mathrm{Ca}$ on freshly collected corals. These results indicate that metabolic-derived $\mathrm{C}$ only plays a minor role as $\mathrm{C}$ source for calcification, which confirms the suggestion by Adkins et al. (2003) based on isotopic data analysis in the coral skeleton $\left(\delta^{18} \mathrm{O}, \delta^{13} \mathrm{C}\right)$, that calcification of $L$. pertusa mainly relies on an external DIC source which decreases the effect of isotopic fractionation during the calcification process. This makes $L$. pertusa skeletons an excellent study object for climatic reconstructions (Adkins et al., 2003).

\section{Conclusions and implications}

In this study we investigated the capability of $L$. pertusa to take up different food sources ranging from dissolved organic matter, bacteria and algae to zooplankton. The comparable assimilation rates of the different food sources hereby indi- cated that $L$. pertusa is an opportunistic feeder that is able to exploit a wide variety of food sources even including DOM.

Our main focus was to investigate the uptake of food sources across a broad size spectrum, but the implications of these findings for field conditions depend partly on how representative the experimental food sources are for natural conditions. Zooplankton can be an important food item for CWCs (Freiwald, 2002; Kiriakoulakis et al., 2005; Dodds et al., 2009; Duineveld et al., 2012), but it is logistically challenging to use local and living copepod species in laboratory studies, especially when these need to be enriched with stable isotopes. Therefore, we decided to use laboratoryreared Artemia as substitute for natural zooplankton, like most other feeding studies (Purser et al., 2010; Tsounis et al., 2010; Larsson et al., 2013b). Although Artemia may differ from copepods in their biochemical composition (Evjemo and Olsen, 1996; Helland et al., 2003), they are in the same size range as natural copepods. The microalgae selected for experimentation, Skeletonema costatum, contributes to phytoplankton blooms in the Skagerrak (Lange et al., 1992) and, together with dissolved organic matter, may reach the Lophelia reefs during downwelling events (Wagner et al., 2011). The cultured bacteria used in the experiment likely differed in composition from that in nature, but it gives first-order information about how $L$. pertusa deals with the natural picoplankton fraction comprising a broad variety of microbes (bacteria, eukarya and archaea, Jensen et al., 2012). We are therefore confident that our experimental food sources are good representatives for natural food items and are able to illustrate the opportunistic feeding strategy of the coral.

The ability to utilize DOM hereby underlines the nutritional flexibility of $L$. pertusa and might be especially relevant for natural reefs like on Rockall bank, where POM concentrations can be very low during several months (Duineveld et al., 2007). The assimilation of external DOM and the re-assimilation of DOM from coral mucus release, responsible for high labile DOM concentrations above CWC reefs (van Duyl et al., 2008; Wild et al., 2009) might help the coral to withstand several months without POM supply.

Next to the uptake of different sized food source, we also explored for the first time the processing of these sources by $L$. pertusa. The observed differences in food processing hereby suggest that the nutritional value of a food source is at least partly determined by its composition (quantity and quality of fatty acids and amino acids). Our findings further indicate that phytoplankton is a valuable resource for $L$. pertusa due to the efficient transformation into coral fatty acids. This might be especially relevant in locations where downwelling events (Tisler Reef, Mingulay Reef) supply the reefs with a high availability of phytoplankton (Duineveld et al., 2004; Davies et al., 2009; Wagner et al., 2011). Furthermore, the high flow velocities characterizing many CWC reef locations (Messing, 1990; Thiem et al., 2006; White et al., 2007) might also favor the uptake of smaller particles such as algae, since particle retention is negatively affected by particle 
size especially at higher flow velocities (Shimeta and Koehl, 1997).

Additionally, we found de novo synthesis within the fatty acid metabolism, indicating that corals do not only rely on dietary fatty acids to obtain certain fatty acids. This especially concerns bacteria, since they are often considered as low quality food based on their lack of long-chain fatty acids (Phillips, 1984; Leroy et al., 2012). However, given the ability of the coral to synthesized long-chain fatty acids such as $\mathrm{C} 22: 2 \omega 6$ and $\mathrm{C} 22: 1 \omega 9 \mathrm{c}$ from bacteria, our results suggest that bacteria can be a valuable addition to coral nutrition. This might be especially relevant since bacteria occur in high abundance around cold-water coral reefs and food uptake in $L$. pertusa is positively correlated with prey abundance (Purser et al., 2010). Additionally, bacteria are constantly available to the coral since they are fertilized by the coral itself via mucus production (Wild et al., 2009; Maier et al., 2011), while POM availability can vary spatially and temporally (Duineveld et al., 2007).

Acknowledgements. This research was supported by the CALMARO project (FP7/2008-2012), funded by the European Community's Seventh Framework Programme (FP7/2008-2012) and the CORAMM project funded by Statoil. T. Lundälv is thanked for collecting the corals by ROV and providing lab space and equipment. We thank the analytical lab of NIOZ-Yerseke for sample analysis and P. van Rijswijk for his help during the culturing work.

Edited by: G. Herndl

\section{References}

Achituv, Y., Ben-Zion, M., and Mizrahi, L.: Carbohydrate, lipid, and protein composition of zooxanthellae and animal fractions of the coral Pocillopora damicornis exposed to ammonium enrichment, Pac. Sci., 48, 224-233, 1994.

Adkins, J. F., Boyle, E. A., Curry, W. B., and Lutringer, A.: Stable isotopes in deep-sea corals and a new mechanism for "vital effects", Geochim. Cosmochim. Ac., 67, 1129-1143, doi:10.1016/S0016-7037(00)01203-6, 2003.

Boschker, H. T. S., de Brouwer, J. F. C., and Cappenberg, T. E.: The contribution of macrophyte-derived organic matter to microbial biomass in salt-marsh sediments: Stable carbon isotope analysis of microbial biomarkers, Limnol. Oceanogr., 44, 309-319, 1999.

Braeckman, U., Provoost, P., Sabbe, K., Soetaert, K., Middelburg, J. J., Vincx, M., and Vanaverbeke, J.: Temporal dynamics in the diet of two marine polychaetes as inferred from fatty acid biomarkers, J. Sea Res., 68, 6-19, doi:10.1016/j.seares.2011.11.003, 2012.

Buhl-Mortensen, P.: Aquarium observations on the deep-water coral Lophelia pertusa (L., 1758) (scleractinia) and selected associated invertebrates, Ophelia, 54, 83-104, 2001.

Davies, A. J., Duineveld, G. C. A., Lavaleye, M. S. S., Bergman, M. J. N., van Haren, H., and Roberts, J. M.: Downwelling and deep-water bottom currents as food supply mechanisms to the cold-water coral Lophelia pertusa (Scleractinia) at the
Mingulay Reef complex, Limnol. Oceanogr., 54, 620-629, doi:10.4319/lo.2009.54.2.0620, 2009.

Davies, A. J. and Guinotte, J. M.: Global Habitat Suitability for Framework-Forming Cold-Water Corals, Plos One, 6, e18483, doi:10.1371/journal.pone.0018483, 2011.

Dodds, L. A., Black, K. D., Orr, H., and Roberts, J. M.: Lipid biomarkers reveal geographical differences in food supply to the cold-water coral Lophelia pertusa (Scleractinia), Mar. Ecol. Prog. Ser., 397, 113-124, doi:10.3354/meps08143, 2009.

Duineveld, G. C. A., Lavaleye, M. S. S., and Berghuis, E. M.: Particle flux and food supply to a seamount cold-water coral community (Galicia Bank, NW Spain), Mar. Ecol. Prog. Ser., 277, 13-23, 2004.

Duineveld, G. C. A., Lavaleye, M. S. S., Bergman, M. I. N., De Stigter, H., and Mienis, F.: Trophic structure of a cold-water coral mound community (Rockall Bank, NE Atlantic) in relation to the near-bottom particle supply and current regime, B. Mar. Sci., 81 , 449-467, 2007.

Duineveld, G. C. A., Jeffreys, R. M., Lavaleye, M. S. S., Davies, A. J., Bergman, M. J. N., Watmough, T., and Witbaard, R.: Spatial and tidal variation in food supply to shallow cold-water coral reefs of the Mingulay Reef complex (Outer Hebrides, Scotland), Mar. Ecol. Prog. Ser., 444, 97-115, doi:10.3354/meps09430, 2012.

Evjemo, J. O. and Olsen, Y.:, Lipid and fatty acid content in cultivated live feed organisms compared to marine copepods, Hydrobiologia, 358, 159-162, 1996.

Frederiksen, R., Jensen, A., and Westerberg, H.: The distribution of the scleractinian coral Lophelia pertusa around the Faroe Islands and teh relation to internal tidal mixing, Sarsia, 77, 157171, 1992.

Freiwald, A.: Reef-forming cold-water corals, Ocean margin systems, edited by: Wefer, G., Billett, D., Hebbeln, D., Jorgensen, B. B., Schluter, M., and van Weering, T., Springer-Verlag, Berlin/Heidelberg/New York, 365-385, 2002.

Freiwald, A., Huhnerbach, V., Lindberg, B., Wilson, J. B., and Campbell, J.: The Sula Reef Complex, Norwegian shelf, Facies, 47, 179-200, doi:10.1007/bf02667712, 2002.

Furla, P., Galgani, I., Durand, I., and Allemand, D.: Sources and mechanisms of inorganic carbon transport for coral calcification and photosynthesis, J. Exp. Biol., 203, 3445-3457, 2000.

Grover, R., Maguer, J. F., Allemand, D., and FerrierPagès, C.: Urea uptake by the scleractinian coral Stylophora pistillata, J. Exp. Mar. Biol. Ecol., 332, 216-225, doi:10.1016/j.jembe.2005.11.020, 2006

Grover, R., Maguer, J.-F., Allemand, D., and Ferrier-Pagès, C.: Uptake of dissolved free amino acids by the scleractinian coral Stylophora pistillata, J. Exp. Biol., 211, 860-865, doi:10.1242/jeb.012807, 2008.

Harwood, J. L. and Russell, N. L.: Lipids in plants and microbes, George Allen and Unwin, London, 1-6, 1984

Helland, S., Terjesen, B. F., and Berg, L.: Free amino acids and protein content in the planktonic copepod Temora longicornis compared to Artemia franciscana, Aquaculture, 215, 213-228, 2003.

Hind, A., Gurney, W. S. C., Heath, M., and Bryant, A. D.: Overwintering strategies in Calanus finmarchicus, Marine Ecol.-Prog. Ser., 193, 95-107, doi:10.3354/meps193095, 2000.

Hoegh-Guldberg, O. and Williamson, J.: Availability of two forms of dissolved nitrogen to the coral Pocillopora damicor- 
nis and its symbiotic zooxanthellae, Mar. Biol., 133, 561-570, doi:10.1007/s002270050496, 1999.

Jensen, S., Bourne, D. G, Hovland, M., and Murrell, J. C.: High diversity of microplankton surrounds deep-water coral reef in the Norwegian Sea, FEMS Microbiol. Ecol., 82, 75-89, 2012.

Kelly, J. R. and Scheibling, R. E.: Fatty acids as dietary tracers in benthic food webs, Mar. Ecol. Prog. Ser., 446, 1-22, 2012.

Kiriakoulakis, K., Fisher, E., Wolff, G. A., Freiwald, A., Grehan, A., and Roberts, J. M.: Lipids and nitrogen isotopes of two deepwater corals from the North-East Atlantic, initial results and implications for their nutrition, Cold-Water Corals and Ecosystems, edited by: Freiwald, A. and Roberts, J. M., 715-729, 2005.

Lange, C. B., Hasle, G. R., and Syvertsen, E. E.: Seasonal cycle of diatoms in the Skagerrak, North Atlantic, with emphasis on the period 1980-1990, Sarsia, 77, 173-187, 1992.

Larsson, A. I., van Oevelen, D., Purser, A., and Thomsen, L.: Tolerance to long-term exposure of suspended benthic sediments and drill cuttings in the cold-water coral Lophelia pertusa, Mar. Pollut. Bull., 70, 176-188, doi:10.1016/j.marpolbul.2013.02.033, 2013a.

Larsson, A. I., Lundälv, T., and van Oevelen, D.: Skeletal growth, respiration rate and fatty acid composition in the cold-water coral Lophelia pertusa under varying food conditions, Mar. Ecol. Prog. Ser., 483, 169-184, doi:10.3354/meps 10284, 2013 b.

Lavaleye, M., Duineveld, G., Lundälv, T., White, M., Guihen, D., Kiriakoulakis, K., and Wolff, G. A.: Cold-Water Corals on the Tisler Reef- preliminary observations on the dynamic reef environment, Oceanography, 22, 76-84, 2009.

Leroy, F., Riera, P., Jeanthon, C., Edmond, F., Leroux, C., and Comtet, T.: Importance of bacterivory and preferential selection toward diatoms in larvae of Crepidula fornicata (L.) assessed by a dual stable isotope (C-13, N-15) labeling approach, J. Sea Res., 70, 23-31, doi:10.1016/j.seares.2012.02.006, 2012.

Lucas, J. M. and Knapp, L. W.: A physiological evaluation of carbon sources for calcification in the octocoral Leptogorgia virgulata (Lamarck), J. Exp. Biol., 200, 2653-2662, 1997.

Maier, C., Hegeman, J., Weinbauer, M. G., and Gattuso, J.-P.: Calcification of the cold-water coral Lophelia pertusa, under ambient and reduced $\mathrm{pH}$, Biogeosciences, 6, 1671-1680, doi:10.5194/bg6-1671-2009, 2009.

Maier, C., de Kluijver, A., Agis, M., Brussaard, C. P. D., van Duyl, F. C., and Weinbauer, M. G.: Dynamics of nutrients, total organic carbon, prokaryotes and viruses in onboard incubations of coldwater corals, Biogeosciences, 8, 2609-2620, doi:10.5194/bg-82609-2011, 2011.

McLeod, R. J., Hyndes, G. A., Hurd, C. L., and Frew, R. D.: Unexpected shifts in fatty acid composition in response to diet in a common littoral amphipod, Mar. Ecol. Prog. Ser., 479, 1-12, doi:10.3354/meps10327, 2013.

Messing, C., G., C. A., Neumann, C. A., and Lang, J. C.: Biozonation of deep-water lithoherms and associated hardgrounds in the northeastern Straits of Florida, Palaios, 5, 15-33, 1990.

Mueller, C. E., Lundälv, T., Middelburg, J. J., and van Oevelen, D.: The symbiosis between Lophelia pertusa and Eunice norvegica stimulates coral calcification and worm assimilation, Plos One, 8, e58660, doi:10.1371/journal.pone.0058660, 2013.

Naumann, M. S., Orejas, C., Wild, C., and Ferrier-Pagès, C.: First evidence for zooplankton feeding sustaining key physiological processes in a scleractinian cold-water coral, J. Exp. Biol., 214, 3570-3576, doi:10.1242/jeb.061390, 2011.

Phillips, N. W.: Role of Different Microbes and Substrates as Potential Suppliers of Specific, Essential Nutrients to Marine Detritivores, B. Mar. Sci., 35, 283-298, 1984.

Purser, A., Larsson, A. I., Thomsen, L., and van Oevelen, D.: The influence of flow velocity and food concentration on Lophelia pertusa (Scleractinia) zooplankton capture rates, J. Exp. Mar. Biol. Ecol., 395, 55-62, doi:10.1016/j.jembe.2010.08.013, 2010.

Roberts, J. M., Wheeler, A. J., and Freiwald, A.: Reefs of the deep, The biology and geology of cold-water coral ecosystems, Science, 312, 543-547, doi:10.1126/science.1119861, 2006.

Roberts, M., Wheeler, A., Freiwald, A., and Cairns, S.: Cold-water corals, The biology and geology of deep-sea coral habitats, Cambridge University Press., New York, 2009a.

Roberts, J. M., Davies, A. J., Henry, L. A., Dodds, L. A., Duineveld, G. C. A., Lavaleye, M. S. S., Maier, C., van Soest, R. W. M., Bergman, M. J. N., Huehnerbach, V., Huvenne, V. A. I., Sinclair, D. J., Watmough, T., Long, D., Green, S. L., and van Haren, H.: Mingulay reef complex: an interdisciplinary study of cold-water coral habitat, hydrography and biodiversity, Mar. Ecol. Prog. Ser., 397, 139-151, doi:10.3354/meps08112, 2009 b.

Sargent, J. R. and Falkpetersen, S.: The lipid biochemistry of calanoid copepods, Hydrobiologia, 167, 101-114, doi:10.1007/bf00026297, 1988.

Shimeta, J. and Koehl, M. A. R.: Mechanisms of particle selection by tentaculate suspension feeders during encounter, retention, and handling, J. Exp. Mar. Biol. Ecol., 209, 47-73, doi:10.1016/s0022-0981(96)02684-6, 1997.

Spiro, B., Roberts, M., Gage, J., and Chenery, S.: O-18/O-16 and C-13/C-12 in an ahermatypic deepwater coral Lophelia pertusa from the North Atlantic, a case of disequilibrium isotope fractionation, Rapid Commun. Mass Sp., 14, 1332-1336, doi:10.1002/1097-0231(20000815), 2000.

Szmant-Froelich, A. and Pilson, M. E. Q.: The effects of feeding frequency and symbiosis with zooxanthellae on the biochemical composition of Astrangia danae Milne Edwards \& Haime 1849, J. Exp. Mar. Biol. Ecol., 48, 85-97, doi:10.1016/00220981(80)90009-X, 1980.

Thiem, O., Ravagnan, E., Fosså, J. H., and Berntsen, J.: Food supply mechanisms for cold-water corals along a continental shelf edge, J. Marine Syst., 60, 207-219, doi:10.1016/j.jmarsys.2005.12.004, 2006.

Tsounis, G., Orejas, C., Reynaud, S., Gili, J. M., Allemand, D., and Ferrier-Pagès, C.: Prey-capture rates in four Mediterranean cold water corals, Mar. Ecol. Prog. Ser., 398, 149-155, doi:10.3354/meps08312, 2010.

Valle-Levinson, A., Castro, A. T., de Velasco, G. G., and Armas, R. G.: Diurnal vertical motions over a seamount of the southern Gulf of California, J. Marine Syst., 50, 61-77, doi:10.1016/j.jmarsys.2003.09.016, 2004.

van Duyl, F. C., Hegeman, J., Hoogstraten, A., and Maier, C.: Dissolved carbon fixation by sponge-microbe consortia of deep water coral mounds in the northeastern Atlantic Ocean, Mar. Ecol. Prog. Ser., 358, 137-150, doi:10.3354/meps07370, 2008.

van Oevelen, D., Duineveld, G., Lavaleye, M., Mienis, F., Soetaert, K., and Heip, C. H. R.: The cold-water coral community as a hot spot for carbon cycling on continental margins, A food-web anal- 
ysis from Rockall Bank (northeast Atlantic), Limnol. Oceanogr., 54, 1829-1844, 2009.

Veuger, B., Middelburg, J. J., Boschker, H. T. S., and Houtekamer, M.: Analysis of N-15 incorporation into D-alanine: A new method for tracing nitrogen uptake by bacteria, Limnol. Oceanogr. Meth., 3, 230-240, 2005.

Wagner, H., Purser, A., Thomsen, L., Jesus, C. C., and Lundälv, T.: Particulate organic matter fluxes and hydrodynamics at the Tisler cold-water coral reef, J. Marine Syst., 85, 19-29, doi:10.1016/j.jmarsys.2010.11.003, 2011.

White, M., Roberts, J. M., and van Weering, T.: Do bottomintensified diurnal tidal currents shape the alignment of carbonate mounds in the NE Atlantic?, Geo-Mar. Lett., 27, 391-397, 10.1007/s00367-007-0060-8, 2007.
Wild, C., Mayr, C., Wehrmann, L., Schoettner, S., Naumann, M., Hoffmann, F., and Rapp, H. T.: Organic matter release by cold water corals and its implication for fauna-microbe interaction, Mar. Ecol. Prog. Ser., 372, 67-75, doi:10.3354/meps07724, 2008.

Wild, C., Wehrmann, L. M., Mayr, C., Schoettner, S. I., Allers, E., and Lundälv, T.: Microbial degradation of cold-water coralderived organic matter: potential implication for organic $\mathrm{C}$ cycling in the water column above Tisler Reef, Aquat. Biol., 7, 7180, doi:10.3354/ab00185, 2009. 